\title{
Pilot-scale study of sludge pretreatment by microwave and sludge reduction based on lysis-cryptic growth
}

\author{
Yawei Wang, Qingcong Xiao, Jibao Liu, Hong Yan, Yuansong Wei* \\ Research Center for Eco-Environmental Sciences, Chinese Academy of Sciences, P.O. Box 2871, Beijing 100085, PR China
}

\section{H I G H L I G H T S}

- Studied microwave (MW) pretreatment in a large pilot-scale sludge reduction system.

- The sludge quantity to be finally disposed off was reduced by $38.60 \%$ on average.

- Achieved $13.64 \%$ cost savings compared to operation without MW pretreatment.

\section{A R T I C L E I N F O}

\section{Article history:}

Received 24 January 2015

Received in revised form 13 April 2015

Accepted 15 April 2015

Available online 20 April 2015

\section{Keywords:}

Microwave pretreatment

Sludge reduction

Pilot-scale

Cost analysis

Hydrogen peroxide

\begin{abstract}
A B S T R A C T
To evaluate the performance of microwave (MW)-chemical hybrid sludge treatment system, a pilot scale MW disintegration unit (treatment capacity of $500 \mathrm{~L} / \mathrm{d}$ ) was constructed. The results showed that organic matter, nitrogen, and phosphorus were effectively released from the MW-pretreated sludge. The values of COD released were $15.91 \%, 15.07 \%, 13.83 \%, 19.35 \%$, and $15.07 \%$ for the MW, MW-acid, MW-alkali, $\mathrm{MW}-\mathrm{H}_{2} \mathrm{O}_{2}$, and $\mathrm{MW}-\mathrm{H}_{2} \mathrm{O}_{2}$-alkali treatment processes, respectively. Additionally, for a wastewater treatment system with a capacity of $200 \mathrm{~m}^{3} / \mathrm{d}$, when coupled with a MW sludge pretreatment unit, the sludge production and sludge yield were greatly reduced by $38.60 \%$ and to $0.35 \mathrm{~kg} \mathrm{VSS} / \mathrm{kg}$ $\mathrm{COD}_{\text {consumed }}$, respectively. The total operating cost of the lysis-cryptic growth system was $13.64 \%$ lower than that of the CAS system without a MW unit.
\end{abstract}

(c) 2015 Elsevier Ltd. All rights reserved.

\section{Introduction}

Biological sewage treatment plants around the world produce large and ever-increasing amounts of excess sludge. Owing to regulatory restrictions and the inadequate availability of landfill sites, sludge treatment and disposal have become serious concerns in the normal operation of sewage treatment systems (Ma et al., 2012; Odegaard, 2004). Improper treatment of the sludge poses major risks to public health. Currently, the treatment and disposal of excess sludge constitute $50-60 \%$ of the operating costs of wastewater treatment plants (WWTPs) (Campos et al., 2009). Therefore, cost-effective disposal of the excess sludge into the environment is a serious challenge faced by researchers.

Reduce, reuse, and recycle (the 3Rs) are the three basic options available for sludge treatment (Romero et al., 2013). Among the 3R treatment options, reducing the amount of sludge produced is regarded as the ideal method for solving the problems associated with sludge treatment. Much effort has been expended in developing sludge disintegration and solubilization techniques that feed

\footnotetext{
* Corresponding author. Tel./fax: +86 1062849690.

E-mail address: yswei@rcees.ac.cn (Y. Wei).
}

back to the biological processing step for further biodegradation (Odegaard, 2004). This type of process is known as lysis-cryptic growth (Guo et al., 2013; Romero et al., 2013; Wang et al., 2009).

In most of the $3 \mathrm{R}$ treatment technologies, breaking the cell walls of the sludge particles is a key problem, owing to the protection offered by the extracellular polymeric substances (EPS). Therefore, pretreatment technologies can be used to disrupt the cell walls, which also help improve biogas production, recover materials such as proteins, volatile fatty acids (VFAs), nitrogen, and phosphorus, and improve sludge dewatering. There are many sludge pretreatment technologies available involving physical, chemical, mechanical, or biological hydrolysis, or a combination of these methods (Carrere et al., 2010; Tyagi and Lo, 2011). All the existing pretreatment techniques have their drawbacks, and consequently, an effective and economical pretreatment method is still required (Jang and Ahn, 2013).

The microwave (MW) technology has gained widespread popularity as an effective thermal method for sludge treatment (Tyagi and Lo, 2013). Another promising application of MW technology is in pyrolysis, which involves heating dried sludge at temperatures above $300^{\circ} \mathrm{C}$ in the absence of water and oxygen, to produce valuable gases and oils (Manara and Zabaniotou, 2012). The major 
driving force behind the rise in the use of MW technologies is the fact that heating with MW energy is superior to conventional heating, mainly in terms of its ability to heat rapidly and selectively, thereby accelerating reaction rates. MW heating provides instant on/off control and increases energy efficiency, with the capacity to enhance the yield and quality of the product. In addition, it minimizes hazardous product formation and emissions, thereby rendering the technique environmentally friendly.

Previous studies have reported that significantly higher solubilization of the volatile suspended solids (VSS) can be achieved by combining MW and chemical pretreatment techniques (Tyagi and Lo, 2013). Toward this end, MW-alkali/acid (e.g., MWacid (MW-H) and MW-alkali (MW-OH)) and MW-enhanced advanced oxidation processes $\left(\mathrm{MW} / \mathrm{H}_{2} \mathrm{O}_{2}\right.$-AOP; e.g., $\mathrm{MW}-\mathrm{H}_{2} \mathrm{O}_{2}$ and $\mathrm{MW}-\mathrm{H}_{2} \mathrm{O}_{2}-\mathrm{OH}$ ) have been developed to improve the MW sludge pretreatment performance (Wang et al., 2015). It has been suggested that scaling up is the most important obstacle in the path to full-scale applications of MW-based pretreatment technologies (Tyagi and Lo, 2013). Presently, while there are over 120 papers focused on the MW sludge pretreatment technology (based on the web of science search), most studies so far have been conducted on small laboratory scale, and the results obtained cannot be directly implemented in full-scale applications. Srinivasan et al. (2014) proved the feasibility of MW technology in practical applications by successfully operating a pilot MW oven treating cattle manure. To the best of the authors' knowledge, so far, there have been no large-scale pilot studies assessing the suitability of the MW sludge pretreatment technology or describing the influence of MW pretreatment on subsequent sludge reduction system. Furthermore, because laboratory experiments cannot be used to evaluate the performance of the techniques in practical applications, there have been no thorough evaluations of the economic impact of the MW treatment technology in the WWTPs.

Therefore, we built a pilot-scale lysis-cryptic sludge reduction system consisting of a MW disintegration unit (capacity: $500 \mathrm{~L} / \mathrm{d}$ ) and a conventional activated sludge (CAS) system (capacity: $200 \mathrm{~m}^{3} / \mathrm{d}$ ), with the goal of developing a cost-efficient sludge reduction technology. The objectives of this study were: (1) to evaluate the MW-chemical hybrid treatment in a pilot system; (2) to examine the performance of the pilot system over a long period of time; (3) to evaluate the performance of the integrated system for sludge reduction; and (4) to conduct a cost and energy consumption analysis of the MW treatment system.

\section{Methods}

\subsection{The experiment site}

This study (including the batch and sludge reduction experiments) was carried out in the Jizhuangzi wastewater treatment plant in Tianjin, China. The pilot system consisted of two parts, a MW treatment system (capacity: $500 \mathrm{~L} / \mathrm{d}$ of concentrated sludge) and a CAS system (aeration tank volume: $146.7 \mathrm{~m}^{3}$; sewage treatment capacity: $200 \mathrm{~m}^{3} / \mathrm{d}$ ). A schematic diagram of the integrated wastewater and sewage treatment processes is shown in Fig. S-1. The CAS system has been described in a previous paper (Ma et al., 2012). Details of the main configuration and features of the lysiscryptic growth system are listed in Table 1.

\subsection{Pilot-scale MW apparatus}

An automatic industrial MW oven (JWX-10-W, ) operating at $2450 \mathrm{MHz}$ was designed in-house and assembled by the Julong Corp (Baoding, China). The treatment capacity of the oven was $500 \mathrm{~L} / \mathrm{d}$ (10 batches per day at $50 \mathrm{~L}$ per batch). The power of the
Table 1

Main configuration and facilities of the lysis-cryptic growth system.

\begin{tabular}{|c|c|c|}
\hline No. & Unit & $\begin{array}{l}\text { Specification and parameters (size: } \\
\text { length } \times \text { width } \times \text { height) }\end{array}$ \\
\hline 1 & Sewage tank & Concrete; $37.8 \mathrm{~m}^{3} ; 5.00 \times 2.10 \times 4.20 \mathrm{~m}$ \\
\hline 2 & Thin screen & 304 stainless steel; 80 mesh \\
\hline 3 & Aeration basin & Concrete; $146.7 \mathrm{~m}^{3} ; 8.15 \times 5.00 \times 4.20 \mathrm{~m}$ \\
\hline 4 & Tube settler & $\begin{array}{l}\text { Concrete; } 1.33 \mathrm{~m}^{3} /\left(\mathrm{m}^{2} \mathrm{~h}\right) ; \text { Tube } \Phi 80 \times 1000 ; \\
5.00 \times 3.00 \times 4.20 \mathrm{~m}\end{array}$ \\
\hline 5 & $\begin{array}{l}\text { Recirculation sludge } \\
\text { tank }\end{array}$ & Concrete; $23.4 \mathrm{~m}^{3} ; 5.00 \times 1.30 \times 4.20 \mathrm{~m}$ \\
\hline 6 & Gravity thickener & Steel; $3.85 \mathrm{~m}^{3} ; 1.50 \times 1.50 \times 2.50 \mathrm{~m}$ \\
\hline 7 & $\begin{array}{l}\text { Thickened sludge } \\
\text { storage tank }\end{array}$ & Steel; $2.50 \mathrm{~m}^{3} ; 1.50 \times 1.50 \times 1.50 \mathrm{~m}$ \\
\hline 8 & Microwave oven & $\begin{array}{l}\text { Steel; JWX-10-W; working volume, } 50 \mathrm{~L} \text {; output } \\
\text { power-rating, } 10 \mathrm{~kW} ; 1.5 \times 1.3 \times 1.9 \mathrm{~m}\end{array}$ \\
\hline 9 & Post-reactor & $\begin{array}{l}304 \text { stainless steel; } 2.0 \mathrm{~m}^{3} ; \Phi 1.50 \mathrm{~m} \\
\text { I.D. } \times 2.50 \mathrm{~m} \text { height }\end{array}$ \\
\hline 10 & $\mathrm{NaOH}$ solution tank & Polyethylene; $75 \mathrm{~L}$ \\
\hline
\end{tabular}

MW oven was adjustable and the maximum power was $10 \mathrm{~kW}$. All the components in the MW system including the pumps (sludge influent and acid, alkali, and $\mathrm{H}_{2} \mathrm{O}_{2}$ dosage pumps), sensors (for temperature, $\mathrm{pH}$, and liquid level), and the rotating system (a rotating blade homogenizer) were automatically controlled with a programmable logic controller (PLC, Omron CP1H-40XA with a touch screen console center). A schematic diagram of the experimental MW setup is provided in Fig. S-2.

\subsection{Sludge MW treatment}

The practical performances of five MW-based sludge treatments (i.e., $\mathrm{MW}, \mathrm{MW}$-acid (MW-H), $\mathrm{MW}$-alkali (MW-OH), $\mathrm{MW}-\mathrm{H}_{2} \mathrm{O}_{2}$, and $\mathrm{MW}-\mathrm{H}_{2} \mathrm{O}_{2}-\mathrm{OH}$ ) were compared with batch experiments, using the pilot-scale MW oven described above. The details of the treatment conditions are listed in Table 2 (approaches 1-5). The thickened sludge $(21,500 \mathrm{mg} / \mathrm{L})$ from the gravity thickening tank of the pilot wastewater treatment system was fed to the MW oven for the experiments. The chemical oxygen demand (COD), $\mathrm{NH}_{4}^{+}-\mathrm{N}$, total nitrogen $(\mathrm{TN}), \mathrm{PO}_{4}^{3-}-\mathrm{P}$, and total phosphorus (TP) contents of the thickened sludge fed to the MW oven were $132 \mathrm{mg} / \mathrm{L}, 11.3 \mathrm{mg} / \mathrm{L}$, $22.3 \mathrm{mg} / \mathrm{L}, 3.2 \mathrm{mg} / \mathrm{L}$, and $28.8 \mathrm{mg} / \mathrm{L}$, respectively. The same values were observed for these parameters after MW pretreatment in the pilot-scale system.

\subsection{Sludge reduction experiments}

The sludge reduction system was set up by attaching the MW pretreatment unit to the CAS, as illustrated in Fig. S-1. Activated sludge was discharged from the recirculation sludge tank of the CAS system and sent to the gravity thickening tank. Ten batches of concentrated sludge ( $500 \mathrm{~L} /$ batch) from the gravity thickening tank, with a total suspended solids (TSS) content of approximately $21.5 \mathrm{~g} / \mathrm{L}$, were pumped into the MW treatment apparatus and treated. Then the pretreated sludge was continuously recirculated to the aeration tank using a pump.

During the control period (days 1-29) the sludge treated by MW was not recirculated to the CAS system. During this time, the influent flow rate for the CAS system was $200 \mathrm{~m}^{3} / \mathrm{d}$ with a hydraulic retention time (HRT) of $11.74 \mathrm{~h}$. During days 30-60, the sludge treated by the MW unit was recirculated to the CAS system. During this period, the MW-alkali treatment approach (approach 3; Table 2) was used to treat the sludge. This treatment technique was chosen from the results of initial experiments comparing the performance of the various MW-based treatment techniques. 
Table 2

Operating parameters of the MW-based treatment processes and a comparison of the release of various components in the lab-scale and pilot-scale experiments.

\begin{tabular}{|c|c|c|c|c|c|c|c|c|c|}
\hline \multirow[t]{2}{*}{ No. } & \multirow[t]{2}{*}{ Treatment } & \multicolumn{5}{|c|}{$\begin{array}{l}\text { Specific matter released } \\
\text { (mg/g Dry wt.) }\end{array}$} & \multirow[t]{2}{*}{ Treatment procedure } & \multirow[t]{2}{*}{$\begin{array}{l}\text { Treatment } \\
\text { volume }\end{array}$} & \multirow[t]{2}{*}{ Reference } \\
\hline & & COD & $\mathrm{NH}_{4}^{+}-\mathrm{N}$ & TN & $\mathrm{PO}_{4}^{3-}-\mathrm{P}$ & $\mathrm{TP}$ & & & \\
\hline 1 & MW & 152.93 & 4.71 & 6.08 & 1.02 & 1.30 & Raise the temperature to $100^{\circ} \mathrm{C}$ solely by $10 \mathrm{~kW}$ MW & $50 \mathrm{~L}$ & This study \\
\hline 2 & MW-H & 144.56 & 1.49 & 5.17 & 1.04 & 1.43 & Adjusted $\mathrm{pH}$ to 2.5 by $5 \mathrm{M} \mathrm{HCl}$, Then treated similar to approach 1 & & \\
\hline 3 & $\mathrm{MW}-\mathrm{OH}$ & 132.16 & 2.46 & 5.85 & 1.00 & 1.14 & Adjusted $\mathrm{pH}$ to 10 with $5 \mathrm{M} \mathrm{NaOH}$, Then treated similar to approach 1 & & \\
\hline 4 & $\mathrm{MW}-\mathrm{H}_{2} \mathrm{O}_{2}$ & 187.35 & 2.63 & 8.27 & 1.46 & 1.60 & $\begin{array}{l}\text { Dosed } \mathrm{H}_{2} \mathrm{O}_{2}\left(30 \% \mathrm{w} / \mathrm{w}, \mathrm{H}_{2} \mathrm{O}_{2} / \mathrm{TSS} \text { of } 0.2 \mathrm{w} / \mathrm{w}\right) \text { at } 80^{\circ} \mathrm{C} \text {, then heated the } \\
\text { sludge to } 100{ }^{\circ} \mathrm{C}\end{array}$ & & \\
\hline 5 & $\begin{array}{l}\mathrm{MW}- \\
\mathrm{H}_{2} \mathrm{O}_{2}-\mathrm{OH}\end{array}$ & 144.56 & 2.43 & 6.58 & 1.57 & 1.25 & Adjusted pH to 10 with $5 \mathrm{M} \mathrm{NaOH}$, then followed approach 4 & & \\
\hline 6 & MW-OH & 169.80 & 3.79 & 7.58 & 1.42 & 2.52 & Same as approach 3 , average of 60 days & $50 \mathrm{~L}$ & This study \\
\hline 7 & $\mathrm{MW}-\mathrm{OH}$ & 273.90 & 1.48 & 8.50 & & 2.79 & Same as approach 3 in the lab-scale experiment & $300 \mathrm{~mL}$ & $\begin{array}{l}\text { Unpublished } \\
\text { data }\end{array}$ \\
\hline 8 & $\mathrm{MW}-\mathrm{H}_{2} \mathrm{O}_{2}$ & 253.05 & 2.38 & 11.06 & - & 3.62 & $\mathrm{pH} 7,100^{\circ} \mathrm{C}, \mathrm{H}_{2} \mathrm{O}_{2} /$ TSS $1: 1$ & $300 \mathrm{~mL}$ & $\begin{array}{l}\text { Wang et al. } \\
(2015)\end{array}$ \\
\hline 9 & $\begin{array}{l}\mathrm{MW}- \\
\mathrm{H}_{2} \mathrm{O}_{2}-\mathrm{OH}\end{array}$ & 303.04 & 5.09 & 10.78 & - & 4.61 & $\mathrm{pH} 10,100^{\circ} \mathrm{C}, \mathrm{H}_{2} \mathrm{O}_{2} /$ TSS $1: 1$ & & \\
\hline 10 & MW- $\mathrm{H}_{2} \mathrm{O}_{2}$ & 290 & 15 & - & 1.50 & - & $\mathrm{pH} 7.8$, and heated to $120^{\circ} \mathrm{C}$ & $30 \mathrm{~mL}$ & $\begin{array}{l}\text { Kenge et al. } \\
(2009)\end{array}$ \\
\hline
\end{tabular}

- indicates that data was not available in the report cited.

The sludge yield $\left(Y_{\text {obs }}\right)$ was calculated as the ratio of the amount of biomass produced to the amount of substrate consumed ( $\mathrm{g}$ biomass/g substrate) (Metcalf and Eddy, 2003). This parameter is widely used to evaluate the sludge reduction potential of a process; the procedure for the calculation of $Y_{\mathrm{obs}}$ is described in Section 2.5.

\subsection{Analysis and calculations}

Samples of effluent from the pilot system were filtered using a $0.45 \mu \mathrm{m}$ membrane and the concentrations of soluble substances in the filtrate were determined. The COD values were determined after the removal of residual $\mathrm{H}_{2} \mathrm{O}_{2}$ by adding catalase (Sigma $\mathrm{C}$ 9322) (Wang et al., 2009). The total COD (TCOD) and soluble COD (SCOD) were determined using the HACH COD reagent and the DR 2800 colorimeter (HACH, USA). The amounts of TSS, VSS, ammonium, $\mathrm{TN}, \mathrm{PO}_{4}^{3+}-\mathrm{P}$, and $\mathrm{TP}$ were determined using standard methods (China EPA, 2002).

Sludge disintegration effectiveness was evaluated using the degree of disintegration (DD), which is defined as the ratio of the percentage of COD released in the bulk solution to the total COD of the suspended solids. DD is regarded as a key parameter in the evaluation of the pretreatment efficiency (Zhang et al., 2012), and was calculated using the following equation (Eq. (1)):

$\mathrm{DD}(\%)=\frac{\mathrm{SCOD}_{\mathrm{after}}-\mathrm{SCOD}_{0}}{\mathrm{TCOD}_{0}-\mathrm{SCOD}_{0}} \times 100$

In the above equation, $\mathrm{SCOD}_{\text {after }}(\mathrm{mg} / \mathrm{L})$ denotes the soluble COD of the pretreated sludge, $\mathrm{SCOD}_{0}(\mathrm{mg} / \mathrm{L})$ denotes the soluble COD of the initial sludge, and $\mathrm{TCOD}_{0}(\mathrm{mg} / \mathrm{L})$ is the total COD of the initial sludge.

The observed biomass yield $\left(Y_{\text {obs }}\right)$ of the CAS system was calculated using Eq. (2) (Ma et al., 2012):

$Y_{\text {obs }}\left(\operatorname{kgVSS} / \operatorname{kgCOD} D_{\text {removed }}\right)=\frac{1000 \times W}{Q \times\left(C_{\text {in }}-C_{\text {eff }}\right)}$

where, $W(\mathrm{~kg} \mathrm{VSS} / \mathrm{d})$ is the waste activated sludge discharged from the system, $Q\left(\mathrm{~m}^{3} / \mathrm{d}\right)$ is the flow rate of the wastewater influent to the CAS system, and $\operatorname{COD}_{\text {in }}(\mathrm{mg} / \mathrm{L})$ and $\mathrm{COD}_{\text {eff }}(\mathrm{mg} / \mathrm{L})$ are the COD concentrations of the influent and effluent of the CAS system, respectively.

The sludge reduction efficiency (SRE) can be calculated using Eq. (3):
$\operatorname{SRE}(\%)=\left(1-\frac{Y_{\text {obs treated }}}{Y_{\text {obs control }}}\right) \times 100$

where, $Y_{\text {obs treated }}\left(\mathrm{kg} \mathrm{VSS} / \mathrm{kg} \mathrm{COD}_{\text {consumed }}\right)$ is the observed biomass yield of the CAS system operated with excess sludge pretreatment and recycling, whereas $Y_{\text {obs control }}\left(\mathrm{kg} \mathrm{VSS} / \mathrm{kg} \mathrm{COD}_{\text {consumed }}\right)$ is the observed biomass yield of the CAS system operated without excess sludge pretreatment and recycling.

IBM SPSS Statistics (version 19.0.0) software was employed to conduct the data analysis, with the significance level set to 0.05 .

\section{Results and discussions}

\subsection{Sludge solubilization in the batch and continuous experiments in the pilot system}

For all the five pretreatment methods (MW, MW-H, MW-OH, $\mathrm{MW}-\mathrm{H}_{2} \mathrm{O}_{2}$, and $\mathrm{MW}-\mathrm{H}_{2} \mathrm{O}_{2}-\mathrm{OH}$ ) conducted in the pilot-scale, the COD concentrations in the sludge supernatant increased substantially after the pretreatments, as shown in Fig. 1A. The DD values for the five treatment processes were $15.91 \%, 15.07 \%, 13.83 \%$, $19.35 \%$, and $15.07 \%$, respectively, indicating that the MW irradiation and related treatment disrupted the sludge effectively. Further, the TSS values were reduced to $6.98 \%, 16.28 \%, 31.78 \%$, $30.23 \%$, and $46.51 \%$, for the $\mathrm{MW}, \mathrm{MW}-\mathrm{H}, \mathrm{MW}-\mathrm{OH}, \mathrm{MW}-\mathrm{H}_{2} \mathrm{O}_{2}$, and $\mathrm{MW}-\mathrm{H}_{2} \mathrm{O}_{2}-\mathrm{OH}$ treatments, respectively. Among the five treatment processes, the $\mathrm{MW}-\mathrm{H}_{2} \mathrm{O}_{2}$ process released the COD most effectively.

The nutrient release process is critical for nutrient recovery from the sludge, for use as a fertilizer. However, in the absence of a nutrient recovery unit (i.e., a precipitant tank for struvite recovery), the burden on the CAS system for nutrient removal will increase. The TN content in the sludge supernatant (initially $22.3 \mathrm{mg} / \mathrm{L}$ ) increased by 6.85 times after the MW sludge pretreatment (Fig. 1B). In addition, the TN content increased by 7.9 times, reaching values as high as $200.1 \mathrm{mg} / \mathrm{L}$ after the $\mathrm{MW}-\mathrm{H}_{2} \mathrm{O}_{2}$ sludge treatment. The other three treatment processes also showed similar patterns. TP and $\mathrm{PO}_{4}^{3-}-\mathrm{P}$ were effectively released in the pilotscale system (Fig. 1C). The TP levels increased to 53.32$63.18 \mathrm{mg} / \mathrm{L}$ from an initial value of $28.83 \mathrm{mg} / \mathrm{L}$ in the raw sludge. Among the various MW pretreatment processes, the $\mathrm{MW}-\mathrm{H}_{2} \mathrm{O}_{2}$ combination performed the best. In this study, a large portion of the phosphorus remained in the soluble phase in the influent to 


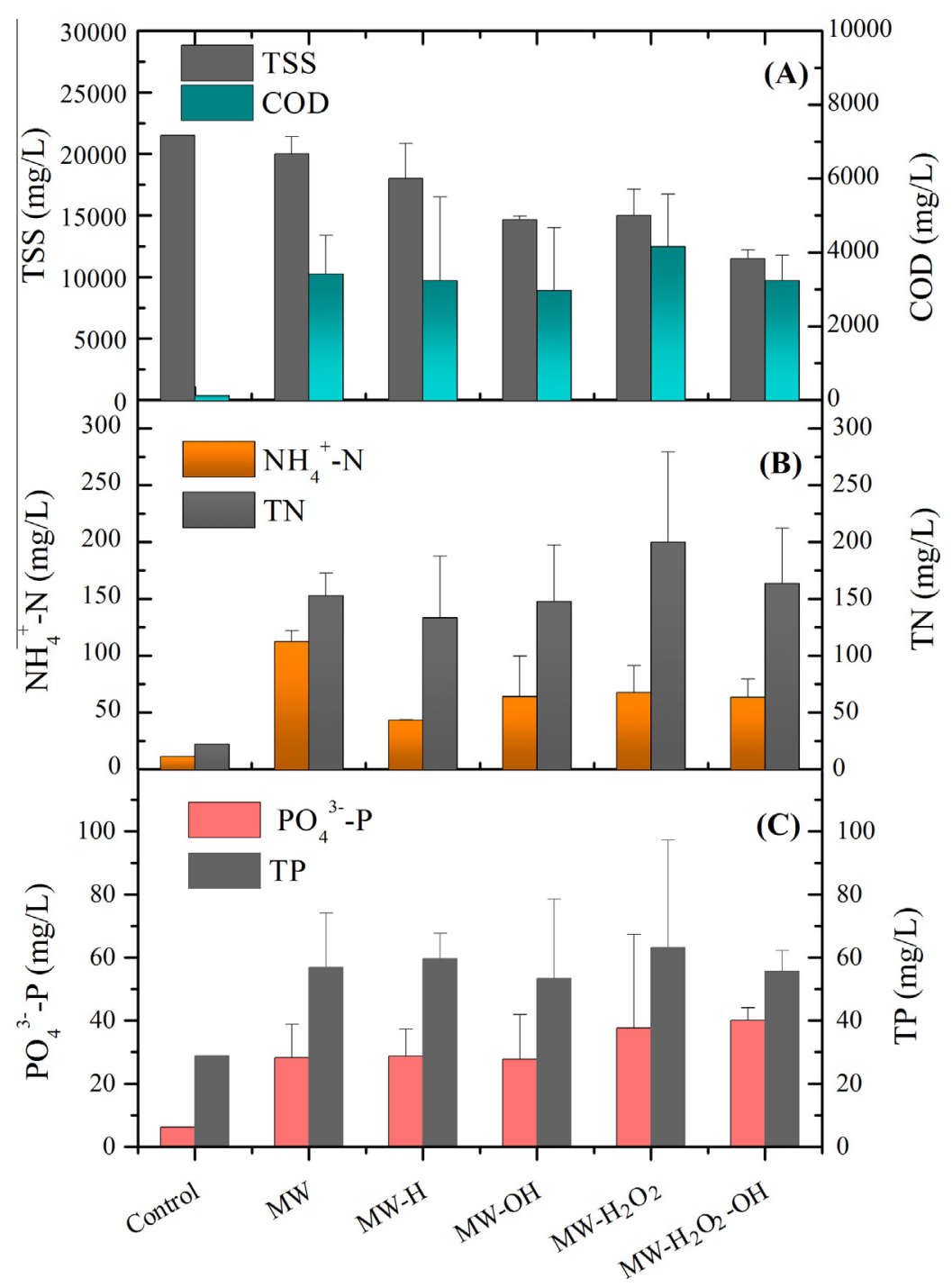

Fig. 1. Variation in TSS, COD, nitrogen, and phosphorus contents after different treatment processes in the pilot-scale experiments.

the pretreatment unit, partially because the phosphate in the sludge thickening tank was released under anaerobic conditions. After the MW treatment process, the $\mathrm{PO}_{4}^{3-}-\mathrm{P}$ release pattern was similar to that of TP (Fig. 1C). The ratio of $\mathrm{PO}_{4}^{3-}-\mathrm{P}$ to TP $\left(\mathrm{PO}_{4}^{3-}-\mathrm{P} /\right.$ $\mathrm{TP}$ ) increased from 0.21 in the supernatant liquor of the raw sludge to $0.50,0.48$, and 0.52 in the cases of $\mathrm{MW}, \mathrm{MW}-\mathrm{H}$, and $\mathrm{MW}-\mathrm{OH}$ treatments, respectively. On the other hand, the $\mathrm{PO}_{4}^{3-}-\mathrm{P} / \mathrm{TP}$ ratios were 0.59 and 0.72 after the $\mathrm{MW}-\mathrm{H}_{2} \mathrm{O}_{2}$ and $\mathrm{MW}-\mathrm{H}_{2} \mathrm{O}_{2}-\mathrm{OH}$ treatments, respectively. It may be noted that a high ratio is beneficial for phosphorus recovery. The $\mathrm{PO}_{4}^{3-}-\mathrm{P} / \mathrm{TP}$ values indicate that $\mathrm{H}_{2} \mathrm{O}_{2}$ facilitates $\mathrm{PO}_{4}^{3-}-\mathrm{P}$ release, as previously suggested by Lo et al. (2010). Wong et al. (2006) found that increasing the hydrogen peroxide concentration resulted in an increase in phosphorus solubilization. The $\mathrm{PO}_{4}^{3-}-\mathrm{P} / \mathrm{TP}$ ratio influences the oxidation effect of the $\mathrm{OH}$ moiety and thereby, facilitates the breakdown of poly-P into $\mathrm{PO}_{4}^{3-}-\mathrm{P}$ in the acid hydrolysis process. The radicals generated during the $\mathrm{MW} / \mathrm{H}_{2} \mathrm{O}_{2}$ pretreatment process convert organic phosphate into the inorganic form (Xiao et al., 2012).

For the solubilization of organic matter, treatment by the MW$\mathrm{H}_{2} \mathrm{O}_{2}$ process was most effective, whereas for reducing the organic matter content, the $\mathrm{MW}-\mathrm{H}_{2} \mathrm{O}_{2}-\mathrm{OH}$ process worked best. This may be attributed to the synergy between $\mathrm{H}_{2} \mathrm{O}_{2}$ and $\mathrm{MW}-\mathrm{H}_{2} \mathrm{O}_{2}$, which can increase the permeability of the cell membranes to the liquid, as a result of which the sludge-dissolved cell effect is improved
(Wang et al., 2015). Erdincler and Vesilind (2000) proved that acids and alkalis work in a variety of ways to break cell walls and membranes. For example, in the case of the saponification reaction, the fatty acids in the cell membranes change the cell membrane permeability by breaking the cell wall or membrane structure. Under alkaline conditions, $\mathrm{H}_{2} \mathrm{O}_{2}$ can easily form $\mathrm{OH}$ radicals, which have strong oxidation capabilities and can transform organic matter into inorganic substances (Xiao et al., 2012).

Considering the safety issues and complexity of storing and dosing $\mathrm{H}_{2} \mathrm{O}_{2}$, MW-alkali treatment was selected to achieve lysiscryptic growth in the long duration sludge reduction operation. The sludge properties before and after MW-alkali treatment for 30 days are shown in Fig. 2. The organic matter (COD), TN, ammonia, and phosphate concentrations were $165 \pm 117 \mathrm{mg} / \mathrm{L}$, $19.33 \pm 7.54 \mathrm{mg} / \mathrm{L}, \quad 14.85 \pm 6.70 \mathrm{mg} / \mathrm{L}, \quad$ and $\quad 16.15 \pm 4.06 \mathrm{mg} / \mathrm{L}$, respectively, before the MW-alkali treatment and increased to $2815 \pm 897 \mathrm{mg} / \mathrm{L}, \quad 136.14 \pm 30.01 \mathrm{mg} / \mathrm{L}, \quad 73.74 \pm 15.36 \mathrm{mg} / \mathrm{L}$, and $39.02 \pm 11.20 \mathrm{mg} / \mathrm{L}$, respectively, after the MW-alkali treatment.

\subsection{Release characteristics of the sludge}

Organic and nutrient matter release were primarily affected by the MW pretreatment. TSS (Wang et al., 2015) was used as a proxy for analyzing the degree of organic and nutrient matter release. 


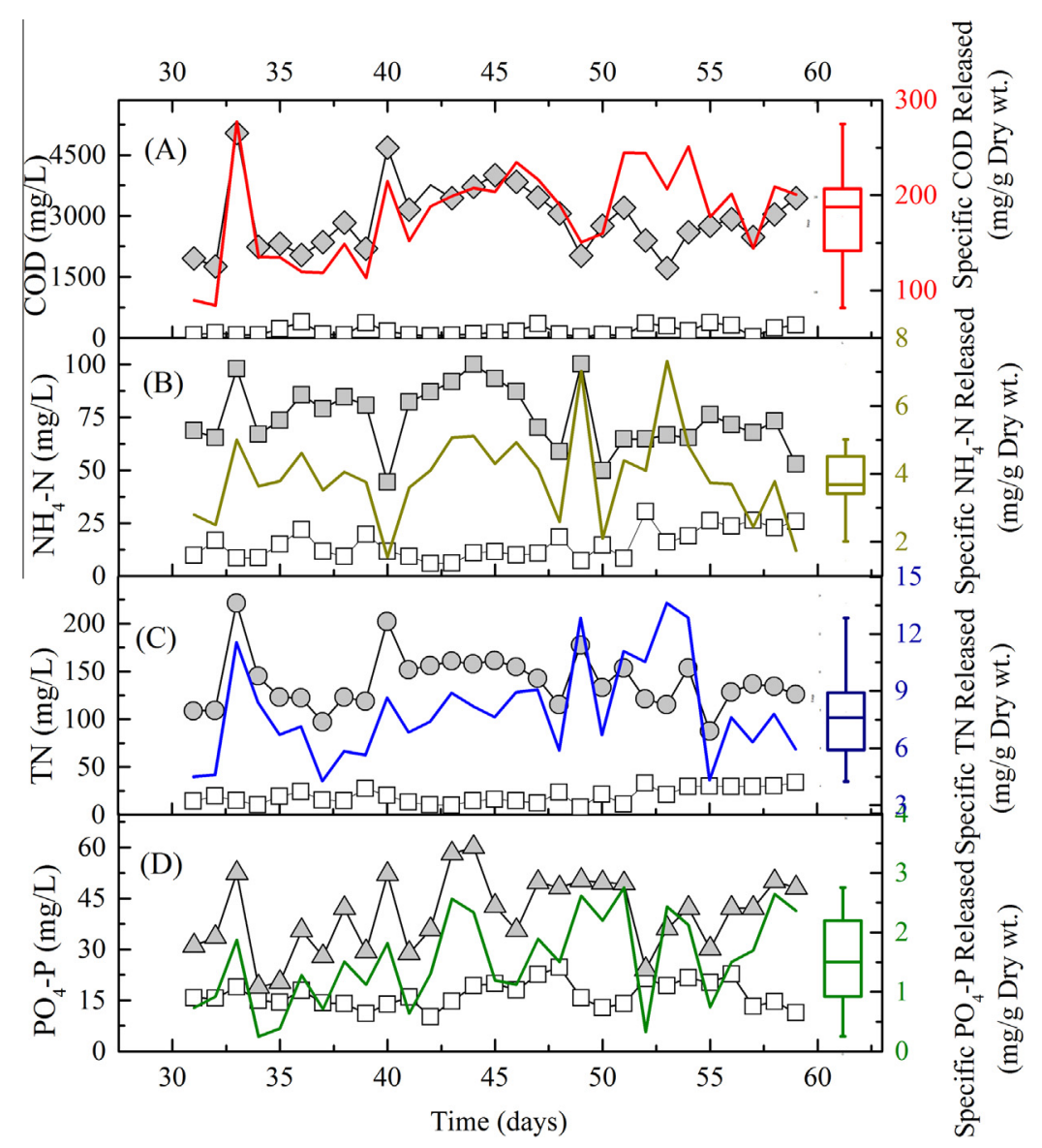

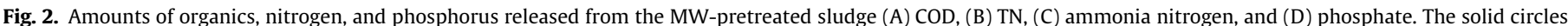

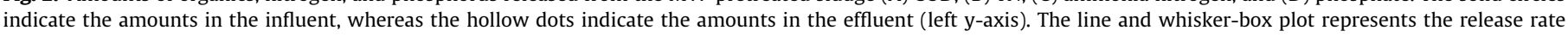
distribution (right y-axis).

The TSS values obtained after treatment with various MW-based treatment processes were evaluated and the specific matter released, i.e., the amount of matter released by a unit mass of sludge, was calculated (Table 2). As evident from the calculated specific COD and nutrient released values, the $\mathrm{MW}-\mathrm{H}_{2} \mathrm{O}_{2}$ process was the optimal pretreatment technique. The maximum value of COD in the pilot-scale treatment involving the $\mathrm{MW}-\mathrm{H}_{2} \mathrm{O}_{2}$ process was $187.35 \mathrm{mg} / \mathrm{g}$ of sludge, which was $75.04 \%$ of the corresponding value obtained in the lab-scale experiment for the same sludge and treatment procedure. Unlike the COD release pattern, the ammonia nitrogen and TN released in the pilot-scale were superior to the lab-scale tests. The TN was released most effectively in the pilotscale with the $\mathrm{MW}-\mathrm{H}_{2} \mathrm{O}_{2}$ technique.

The specific release percentages of organic and nutrient matter during 30 days of continuous sludge pretreatment by the $\mathrm{MW}-\mathrm{OH}$ treatment process are listed in Table 2 (treatment 6 ). The ratios of the standard deviation to the average for the treated sludge were $0.34,0.36,0.36$, and 0.51 for the specific release rates of COD, TN, ammonia, and phosphate, respectively. Since the sludge was treated with automatic PLC control for 30 days, the large variance in the sludge treatment performance indicated that the process was substantially influenced by the sludge properties. As shown in Fig. 2, the variation in the specific matter released indicates large-scale inhomogeneity and reproducibility issues. As the concentration of the sludge has an important influence on the sludge treatment performance (Wang et al., 2015), a sludge thickener should be considered as a key unit in the process design.
There may be several reasons for the inferior performance of the pilot-scale experiments compared to the lab-scale experiments. (1) The penetration depth of the MW radiation is affected by the MW frequency. MW energy may penetrate to a depth of up to $50 \mathrm{~cm}$ for materials with a low-loss factor, but to only a few centimeters for high-loss materials such as water (Tyagi and Lo, 2013). In the case of the primary sludge, the penetration depth was $17 \mathrm{~mm}$ $(2.45 \mathrm{GHz})$, and it was $11 \mathrm{~mm}$ for the primary and secondary sludge (Jang and Ahn, 2013). However, the height of the treatment container (PVC cylinder with a diameter of $0.8 \mathrm{~m}$ ) in the MW oven was $10 \mathrm{~cm}$. Therefore, the MW was unable to fully penetrate the height of the treatment container, even with a homogenizing system. It is suggested that using $915 \mathrm{MHz}$ is more economical for applications requiring over $60 \mathrm{~kW}$ of power (Tyagi and Lo, 2013). Deeper penetration into the material can also be achieved at $915 \mathrm{MHz}$. (2) Control of the overflow foam during the treatment was more difficult in the pilot-scale compared to the lab-scale experiment, in the case of treatment with $\mathrm{H}_{2} \mathrm{O}_{2}$. Adopting a larger container to avoid spillage is not recommended, because the empty cavity space is likely to reduce the density of the MW field, and lead to an inefficient use of electric power. Future studies considering treatment with $\mathrm{H}_{2} \mathrm{O}_{2}$ should utilize a closed vessel system. (3) Since some amount of the sludge stays in the transfer pipe in a treatment batch, and is not exposed to MW radiation, a dead zone is formed in the reactor and the system. This may have reduced the overall performance in the pilot-scale experiments. To overcome the drawbacks of the use of MW at the pilot- or 
full-scale, a pipe-type reactor may be more suitable and is recommended.

\subsection{Sludge reduction}

The variance of the COD in the treated sludge and the discharged sludge is shown in Fig. 3. During the control period, the CAS operated in the steady state without MW pretreatment. During steady state operation, the $Y_{\text {obs }}$ of the pilot system and the average observed sludge yield of the WWTP were $0.57 \mathrm{~kg} \mathrm{VSS} / \mathrm{kg}$ COD $_{\text {consumed. The }} Y_{\mathrm{obs}}$ of a CAS process usually falls in the range of 0.4-0.7 (Metcalf and Eddy, 2003). In addition, in a prior study with the same system, the $Y_{\text {obs }}$ was $0.62 \mathrm{~kg} \mathrm{VSS} / \mathrm{kg}$ COD $_{\text {consumed }}$ (Ma et al., 2012). Yan et al. (2013) compared the sludge reduction induced by side stream reactors from the available literature and found that the $Y_{\mathrm{obs}}$ was in the range of 0.09-0.33. The obvious difference lays in the characteristics of the influent wastewater and the treatment system.

During the period with the MW pretreatment and recirculation, the $Y_{\text {obs }}$ value fell to $0.35 \mathrm{~g}$ VSS/g COD, which was significantly lower ( $p=0.047, t$-test) compared to the control period, and the SRE was $38.60 \%$. The decrease in the sludge yield value indicates that the MW treatment has great potential for sludge reduction. In a prior lab-scale study involving a CAS system $(14.4 \mathrm{~L} / \mathrm{d})$ coupled with a MW pretreatment unit, the yield of the MW pretreatment system, $Y_{\text {obs }}$ (g VSS/g COD consumed $)$ was 0.05 , which was lower than the control group sludge production rate of $0.12 \mathrm{~g}$ VSS/g COD consumed. In addition, the SRE was 50.33\% (unpublished data). The value of $Y_{\mathrm{obs}}$ depends on the type of influent. The sludge pretreatment apparatus plays a greater role than merely the lysis of the sludge particles and contributes more to sludge reduction by interfering with the metabolism of the sludge and its retention time. The system in the present study exhibited low sludge production, in general, because both the maintenance metabolism and the endogenous metabolism of the microorganisms were enhanced by the long solids residence time (SRT) (Yan et al., 2013).

The CAS system performs well for organic matter and ammonia nitrogen removal. Deterioration of the effluent, which is common in other lysis-cryptic systems and has been reported in much of the sludge reduction research (Saktaywin et al., 2005), was not observed in the present case, except for the value of TP in the effluent. TP increased from $0.95 \pm 0.65 \mathrm{mg} / \mathrm{L}$ to $1.62 \pm 0.98 \mathrm{mg} / \mathrm{L}$. This was inevitable, since the amount of phosphorus in the discharged sludge reduced, it therefore released into the effluent. This is a

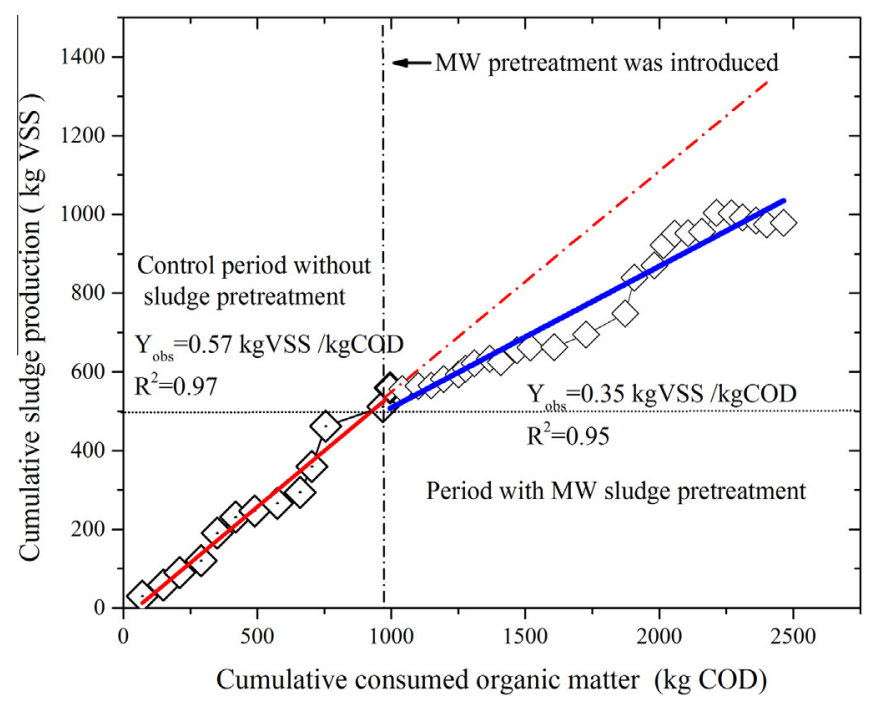

Fig. 3. The observed sludge yield $\left(Y_{\text {obs }}\right)$ of the pilot system during the study period. common drawback of sludge pretreatment unit, for both sludge reduction system with side-stream feedback and anaerobic sludge treatment system (Chiavola et al., 2013). In an ideal system, a nutrient recovery unit (such as a struvite precipitation unit) would be included after sludge pretreatment for phosphate recovery.

\subsection{Cost analysis of the sludge reduction system}

An economic analysis of the continuously operated of the MW sludge treatment system at the pilot-scale was performed. Only the cost for processing the sludge in the MW system and the operating cost were considered. The equipment investment and depreciation costs were not included. In this case, the market price of electricity for industrial use was $\$ 0.115 / \mathrm{kWh}$ in China and the cost of $96 \% \mathrm{NaOH}$ was $\$ 307.70 / \mathrm{t}$. These values and the sludge treatment costs are provided elsewhere (Ma et al., 2012).

The operating cost of a CAS system without pretreatment of the excess sludge includes the costs associated with wastewater treatment in the CAS system and sludge treatment and disposal. For a daily treatment capacity of $200 \mathrm{~m}^{3}$, the electricity consumption of the CAS system arising from influent wastewater pumping, sludge recirculation, excess sludge discharge, and air compressor operation amounted to $258 \mathrm{kWh} / \mathrm{d}$. The excess sludge production of the CAS system was $54.12 \mathrm{~kg} / \mathrm{d}$ (dry solid). The details of the calculations are described in Supplementary information. Therefore, the total operating cost of the CAS system without excess sludge pretreatment was determined to be $\$ 0.22 / \mathrm{m}^{3}$ wastewater (Table 3).

In the case of a lysis-cryptic growth system, the operating cost consists of the wastewater treatment cost, sludge treatment and disposal costs, and the excess sludge pretreatment cost. For the same treatment capacity of $200 \mathrm{~m}^{3} / \mathrm{d}$, the cost of the CAS system in the lysis-cryptic growth system was similar to the case of the CAS system without excess sludge pretreatment. Further, the excess sludge production was $21.96 \mathrm{~kg}$ DS/d for the lysis-cryptic growth system. On the other hand, the wastewater treatment cost was reduced to $\$ 25.56 / \mathrm{d}$, and the operation costs of the MW treatment and the lysis-cryptic system were $\$ 4.94 / \mathrm{d}$. The main contributors to the excess sludge pretreatment cost were electricity $(\$ 4.78 / \mathrm{d})$ and $\mathrm{NaOH}$ consumption $(\$ 0.16 / \mathrm{d})$. Therefore, the total operating cost dropped from $\$ 0.22 / \mathrm{m}^{3}$ wastewater to $\$ 0.19 / \mathrm{m}^{3}$ wastewater, which is $13.64 \%$ less than the cost of the CAS system without excess sludge pretreatment.

The power consumption by the MW transmitter was the largest among the various components of the sludge treatment unit. The pump, MW, and heat exchanger were necessary in the pilot setup. The electricity consumption of the sludge treatment units is shown in Fig. S-3. Among the various energy-consuming components in the treatment unit, the heating energy demand constituted over $72.10 \%$ of the total energy. This was followed by the stirring motor, storage tank agitator, sludge recirculation pump, and MW reactor influent pump, which consumed $14.42 \%, 7.21 \%, 1.5 \%$, and $1.35 \%$ of the total energy. The other components consumed less than $1 \%$ of the total energy.

\subsection{Challenges of the MW pretreatment technology in full-scale applications}

A breakthrough in the sludge MW pretreatment technology can greatly improve the applications of the sludge 3Rs, including dewatering and anaerobic fermentation, and extend the various sludge valorization platforms. While the system investigated in this study proved the effectiveness of MW pretreatment, optimization studies at larger scales and for longer operation periods need to be conducted. The economic feasibility of the MW treatment process can be improved using the following guidelines and recommendations. 
Table 3

A comparison of the operating costs of the CAS system with and without a sludge disintegration system.

\begin{tabular}{|c|c|c|c|}
\hline & Units & $\begin{array}{l}\text { CAS system }(200 \mathrm{t} / \mathrm{d})- \\
\text { No recirculation of sludge }\end{array}$ & $\begin{array}{l}\text { CAS system }(200 \mathrm{t} / \mathrm{d}) \text { with recirculation } \\
\text { of the MW treated sludge }\end{array}$ \\
\hline 1. Cost of wastewater & $\$ / d$ & 25.56 & 25.56 \\
\hline 1.1. Influent pump & $\mathrm{kWh} / \mathrm{d}$ & 19.2 & 19.2 \\
\hline 1.2. Sludge recirculation pump & $\mathrm{kWh} / \mathrm{d}$ & 60 & 60 \\
\hline 1.3. Excess sludge discharge pump & $\mathrm{kWh} / \mathrm{d}$ & 1.1 & 1.1 \\
\hline 2. Sludge disposal & $\$ / d$ & 19.16 & 7.77 \\
\hline 2.1. Chemical (PAM): & $\$ / d$ & 1.20 & 0.49 \\
\hline 2.2. Energy of dewatering & $\$ / d$ & 0.25 & 0.10 \\
\hline 2.3. Maintenance fee for the dewatering equipment & $\$ / d$ & 1.61 & 0.65 \\
\hline 2.4. Sludge transportation & $\$ / d$ & 8.05 & 3.26 \\
\hline 2.5. Sludge land-fill disposal costs & $\$ / d$ & 8.05 & 3.26 \\
\hline 3. Pretreatment and recycling & $\$ / d$ & - & 4.94 \\
\hline 3.1. Chemical $(\mathrm{NaOH})$ & $\$ / d$ & & 0.16 \\
\hline 3.2. Power consumption of the MW reactor & $\$ / d$ & & 4.78 \\
\hline 4. Total cost & $\$ / d$ & 44.72 & 38.27 \\
\hline 5. Total cost for wastewater & $\$ / t$ wastewater & 0.22 & 0.19 \\
\hline
\end{tabular}

(1) In this study, the heat exchanger of the MW treatment system became dysfunctional due to clogging, which is undesirable. Commercial sludge-to-sludge heat exchangers such as sludge spiral heat exchangers and tube-in tube heat exchangers (Metcalf and Eddy, 2003), which are popular in anaerobic digestion systems, should be employed in future MW systems. Temperature differences of less than $3{ }^{\circ} \mathrm{C}$ between fluids can be reached in commercial counter current spiral exchangers (Tranter, 2014). We assume that, if a commercial heat exchanger was applied, the temperature difference between the influent and effluent would be conservatively estimated as less than $10^{\circ} \mathrm{C}$, instead of heating the sludge from its normal temperature of $20^{\circ} \mathrm{C}$ in practical projects. The cost of the MW treatment system used in the present study could be reduced by $63.10 \%$ through the use of high efficiency heat exchange systems, which would make the process more competitive.

(2) In our previous studies on $\mathrm{H}_{2} \mathrm{O}_{2}$ efficiency in treatment systems using $\mathrm{H}_{2} \mathrm{O}_{2}$ (Wang et al., 2009), over 70-90\% of the $\mathrm{H}_{2} \mathrm{O}_{2}$ dose remained in the treated solution. If the utilization of $\mathrm{H}_{2} \mathrm{O}_{2}$ is improved, the dosage of $\mathrm{H}_{2} \mathrm{O}_{2}$ could be significantly reduced. This would reduce the risks of using and storing $\mathrm{H}_{2} \mathrm{O}_{2}$, and thereby promote the application of the MW-combined AOP treatment technology, which has great potential.

(3) During sludge thickening to save energy, the TSS (or water content) was found to be the most important factor that influenced the solubilization of the solid materials (Tang et al., 2010). In this study, the sludge influent to the MW oven had a TSS concentration of $21.5 \mathrm{~g} / \mathrm{L}$. By including a gravity thickening tank, the concentration of the TSS in the sludge could reach as high as 40-60 g/L (Metcalf and Eddy, 2003). In a well-operated gravity thickening separation tank, the energy consumption could be reduced by nearly half, and the treatment capacity could be increased or the space required by the equipment could be reduced.

(4) Once the sludge concentration is increased, the primary problem may be related to the viscosity or the flowability of the sludge, which may affect the performance of the heat exchanger. Therefore, a plug flow pipe reactor with a continuous model (Srinivasan et al., 2014) should be adopted. This could also reduce the energy consumed during homogenizing and stirring.

At present, similar sludge pretreatment technologies (e.g., ultrasonic, $\mathrm{O}_{3}$, conventional heating) are being commercially used for sludge treatment. In the case of MW pretreatment, economic efficiency is one of the bottlenecks limiting its application and popularity. Therefore, the approach needs to be optimized to achieve an economically viable and efficient sludge pretreatment technology. The MW pretreatment technology is likely to be first used in applications such as medical wastewater sludge treatment and disposal facilities with high-risk pathogenic bacteria, or other applications where the sludge quantities are small, but there are strict requirements for hygiene, since the bacteria in the sludge could be completely deactivated by MW irradiation at $100^{\circ} \mathrm{C}$ (Yu et al., 2010) as well as by the use of an oxidant.

\section{Conclusions}

(1) Among the MW-based sludge pretreatment processes, the $\mathrm{MW}-\mathrm{H}_{2} \mathrm{O}_{2}$ process exhibited the best performance with a COD of $19.35 \%$ in the pilot study.

(2) The $Y_{\text {obs }}$ of the CAS coupled with a MW-alkali pretreatment unit in the pilot system was $0.35 \mathrm{~kg}$ VSS $/ \mathrm{kg} \mathrm{COD}_{\text {consumed }}$ which reduced the sludge production by $38.6 \%$. In addition, the water quality of the effluent was satisfactory.

(3) In the pilot study, the total operation cost of the lysis-cryptic growth system was $\$ 0.19 / \mathrm{m}^{3}$ wastewater, which was 13.64\% lower than the CAS system without excess sludge pretreatment.

\section{Acknowledgements}

This work was financially supported by the Major Science and Technology Program for Water Pollution Control and Treatment of China (No. 2012ZX07202-005), the National Natural Science Foundation of China (No. 51008297), and the Hi-Tech Research and Development Program of China (863 Plan) (No. 2007AA06Z347). We appreciate the help of Xuebing Lu, Bo Xi, Huaji Ma, and Shuting Zhang from Tianjin University, and Fanjia Liu and Yingjin Nie from the Research Center of Tianjin Capital Environmental Protection Co. Ltd. (Jizhuangzi Wastewater Treatment Plant, Tianjin, China) for their substantial support.

\section{Appendix A. Supplementary data}

Supplementary data associated with this article can be found, in the online version, at http://dx.doi.org/10.1016/j.biortech.2015.04. 046. 


\section{References}

Campos, J.L., Otero, L., Franco, A., Mosquera-Corral, A., Roca, E., 2009. Ozonation strategies to reduce sludge production of a seafood industry WWTP. Bioresour. Technol. 100, 1069-1073.

Carrere, H., Dumas, C., Battimelli, A., Batstone, D.J., Delgenes, J.P., Steyer, J.P., Ferrer, I., 2010. Pretreatment methods to improve sludge anaerobic degradability: review. J. Hazard. Mater. 183, 1-15.

Chiavola, A., D’Amato, E., Gori, R., Lubello, C., Sirini, P., 2013. Techno-economic evaluation of the application of ozone-oxidation in a full-scale aerobic digestion plant. Chemosphere 91, 656-662.

China EPA, 2002. Standard Methods for Examination of Water and Wastewater Chinese Environmental Science Press, China.

Erdincler, A., Vesilind, P.A., 2000. Effect of sludge cell disruption on compactibility of biological sludges. Water Sci. Technol. 42, 119-126.

Guo, W.Q., Yang, S.S., Xiang, W.S., Wang, X.J., Ren, N.Q., 2013. Minimization of excess sludge production by in-situ activated sludge treatment processes comprehensive review. Biotechnol. Adv. 31, 1386-1396.

Jang, J.H., Ahn, J.H., 2013. Effect of microwave pretreatment in presence of $\mathrm{NaOH}$ on mesophilic anaerobic digestion of thickened waste activated sludge. Bioresour. Technol. 131, 437-442.

Kenge, A., Liao, P.H., Lo, K.V., 2009. Solubilization of municipal anaerobic sludge using microwave-enhanced advanced oxidation process. J. Environ. Sci. Health A 44, 502-506.

Lo, K.V., Chan, W.I., Lo, I.W., Liao, P.H., 2010. The effects of irradiation intensity on the microwave-enhanced advanced oxidation process. J. Environ. Sci. Health A $45,257-262$

Ma, H.J., Zhang, S.T., Lu, X.B., Xi, B., Guo, X.L., Wang, H., Duan, J.X., 2012. Excess sludge reduction using pilot-scale lysis-cryptic growth system integrated ultrasonic/alkaline disintegration and hydrolysis/acidogenesis pretreatment. Bioresour. Technol. 116, 441-447.

Manara, P., Zabaniotou, A., 2012. Towards sewage sludge based biofuels via thermochemical conversion - a review. Renew. Sust. Energy Rev. 16, $2566-$ 2582.

Metcalf, Eddy, 2003. Wastewater Engineering: Treatment and Reuse, fourth ed. McGraw-Hill.

Odegaard, H., 2004. Sludge minimization technologies - an overview. Water Sci. Technol. 49, 31-40.

Romero, P., Coello, M.D., Quiroga, J.M., Aragon, C.A., 2013. Overview of sewage sludge minimisation: techniques based on cell lysis-cryptic growth. Desalin. Water Treat. 51, 5918-5933.
Saktaywin, W., Tsuno, H., Nagare, H., Soyama, T., Weerapakkaroon, J., 2005. Advanced sewage treatment process with excess sludge reduction and phosphorus recovery. Water Res. 39, 902-910.

Srinivasan, A., Nkansah-Boadu, F., Liao, P.H., Lo, K.V., 2014. Effects of acidifying reagents on microwave treatment of dairy manure. J. Environ. Sci. Health B 49, 532-539.

Tang, B., Yu, L., Huang, S., Luo, J., Zhuo, Y., 2010. Energy efficiency of pre-treating excess sewage sludge with microwave irradiation. Bioresour. Technol. 101, 5092-5097.

Tranter, 2014. <http://www.tranter.com/Pages/products/spiral/descriptionbenefits.aspx/> (accessed 22.12.14).

Tyagi, V.K., Lo, S.-L., 2011. Application of physico-chemical pretreatment methods to enhance the sludge disintegration and subsequent anaerobic digestion: an up to date review. Rev. Environ. Sci. Biotechnol. 10, 215-242.

Tyagi, V.K., Lo, S.L., 2013. Microwave irradiation: a sustainable way for sludge treatment and resource recovery. Renew. Sust. Energy Rev. 18, 288-305.

Wang, Y.W., Wei, Y.S., Liu, J.X., 2009. Effect of $\mathrm{H}_{2} \mathrm{O}_{2}$ dosing strategy on sludge pretreatment by microwave- $\mathrm{H}_{2} \mathrm{O}_{2}$ advanced oxidation process. J. Hazard. Mater. $169,680-684$.

Wang, Y., Gui, C., Ni, X., Chen, M., Wei, Y., 2015. Multivariate analysis of sludge disintegration by microwave-hydrogen peroxide pretreatment process. J. Hazard. Mater. 283, 856-864.

Wong, W.T., Chan, W.I., Liao, P.H., Lo, K.V., Mavinic, D.S., 2006. Exploring the role of hydrogen peroxide in the microwave advanced oxidation process: solubilization of ammonia and phosphates. J. Environ. Eng. Sci. 5, 459-465.

Xiao, Q.C., Yan, H., Wei, Y.S., Wang, Y.W., Zeng, F.G., Zheng, X., 2012. Optimization of $\mathrm{H}_{2} \mathrm{O}_{2}$ dosage in microwave- $\mathrm{H}_{2} \mathrm{O}_{2}$ process for sludge pretreatment with uniform design method. J. Environ. Sci. 24, 2060-2067.

Yan, P., Ji, F.Y., Wang, J., Fan, J.P., Guan, W., Chen, Q.K., 2013. Pilot-scale test of an advanced, integrated wastewater treatment process with sludge reduction, inorganic solids separation, phosphorus recovery, and enhanced nutrient removal (SIPER). Bioresour. Technol. 142, 483-489.

Yu, Y., Chan, W.I., Liao, P.H., Lo, K.V., 2010. Disinfection and solubilization of sewage sludge using the microwave enhanced advanced oxidation process. J. Hazard. Mater. 181, 1143-1147.

Zhang, Y.X., Zhang, P.Y., Zhang, G.M., Ma, W.F., Wu, H., Ma, B.Q., 2012. Sewage sludge disintegration by combined treatment of alkaline plus high pressure homogenization. Bioresour. Technol. 123, 514-519. 